failure of the tables in the Japanese light-houses, I feel sure that much of the objectionable innuendo to which I have been subjected would never have been penned.

JoHN MitiNe

s.s. Waihora, Hobart, Tasmania

P.S.-The above has been written whilst at sea, and $I$ have neither had opportunity to refer to books or papers. On my return to Japan I shall be glad to contimue the history of the ball and plate joints, should it be required.

\section{Tremble-terre du 26 Septembre, 1885}

UNE seule secousse a tété constatée le 26 Septembre à oh. $58 \mathrm{~m}$. du matin; elle a été composée de 2 à 3 oscillations, de direction variable suivant les localités. Le centre de la secousse a été dans le milieu du Valais, ou son intensité a été appréciéc comme très-forte, mais où il n'y a cependant pas en de dégâts matériels; il fant hii attribuer le No. VI. de l'échelle qui évalue en dix degrés l'intensité des tremblements de terre.

La secousse s'est étendue vers le nord jusqu'à Schwenden et Zweisimmen dans le Simmenthal, à Château d'Oex, Aigle et Yvorne; dans les Alpes raudoises elle a été fort bien sentie dans les vallées de l'Avençon, de la Gryonne, de la Grande-eau, et de la Savine. Dans tout le reste du canton de Vaud le tremble-terre semble avoir passé inaperçu, tandis qu'il nous est signalé de deux localités fort distantes, Genève et Nidau; il est cependant probable que la secousse de Nidau a précédé de quelque; minutes la grande secousse da Valais; d'après un observatenr très précis la secousse de Nidau a en lieu à oh. $53 \mathrm{~m}$.

En même temps que le sol de la Suisse était ainsi ébranlé, les appareils très délicats de l'observatoire sismique de Rome, qu avaient été en repos les jours précédents, ont signalé des vibra tions du sol vers I heure du matin; et dan; le même nuit un violent tromblement de terre ravageait la ville de Nicolosi près de Catane en Sicile.

Morges, 8 Octobre

\section{Larva of Cerura vinula}

LAST year I was rearing up some larve of Cerura zinula, the Puss Moth, from the egg, and I determined, while I had the chance, to write a life-history of them.

On examining the egg closely $I$ found a small hole in the apex of each, and I thonght at the time that this was probably caused by ichneumons, and therefore I laid the eggss by in a small box that I might capture the ichneumons when they made their appearance. Great was my surprise, then, when 1 found that the young larve came out as usual.

I therefore determined to get some more egss and to find out whether this hole in t'ie apex was caused by the mandibles of the larva insicle, but I found that the larva did not emerge by thi : hole, but by a fresh one made in the side of the egg. And I find that all Puss Moth eggs have this hole in the apex.

I am now hoping to get some eggs of moths belonging to the same family (o.g. Cerura furcula and bifida) to see if they also are perforated in this way. I should be much obliged if any one who has got any of these eggs would kindly let me know whether this is the case.

This hole reaches throngh the shell of the egg, but is covered, on the inside (of the egg) with a thin tissue, like that which is found in birds' eggs.

I have carefully examined several scientific books, but have been unable to find this fact mentioned; therefore I should be much obliged if any one could throw a light on this mysterious fact.

I unfortunately have none of these eggs to forward as examples; but, as they are pretty common in May and June on poplar trees, I have no doubt that such of your readers as are interested in the subject will be able to examine them for themselves.

Draycott Lodge, Fulham, October 9 Cyril B. Holman Huni

\section{Pulsation in the Veins}

I AM quite satisfied that the pulsatory movement in the veins, to which ny former communication referred, is not in any way abnormal, as suggested by Mr. Williams (p. 466). In all cases, without exception-and they have been a good many-in which I have had opportunity for the observation, the minute visille evidence of the pulsatory action has been present, and I have invariably been able to count the pulse of the individuals, as in the experiment detailed in my former letter.

The mirror experiment was tried on my own hand. And a medical friend who applied the sphygmograph in the usual way informed me that my pulse was free from any abnormality.

It is to be borne in mind that the pulsatory indications with which my paper is concerned are exceedingly minute and would escape the perception of nine persons out of ten-requiring an cye educated to appreciate very minute differences of shade and colour. I do not think that the bristles or sealing-wax thread which a correspondent (p. 437) kindly suggests, or even the orthodox sphygmograph would have a chance of effectually exhibiting them. I say shade and colour: for when a vein free from turgidity, and not sensibly altering the smooth surface of the shin, is seen only by its blue track, a modification of the tint is perceptible (to an educated eve); and the blue varies in intensity with the pulsatory action, sufficiently for the success of the pulse-counting experiment.

Stoneaston Park, October 4

J. Hupristey

\section{Stonehenge}

In Nature, vol, xxxii. p. 436 , R. Edmonds associates Stonehenge with the metonic cucle, and quotes from Diodorus Siculus, whom he says fourished about 44 B.C. Would not the latter part of the first century A.D. be more accurate? He gives in his extract from Diodorus Siculus a quotation from Hecataus, whom he confuses with Hecatæus of Miletus, when it was Hecatæus of Abdera to whom Diodorus referred. Hecateus of Miletus flourished about 500 B.C., and Hecatrus of Abdera about 300. Mr. Charles Elton, M.P., in his "Origins of English History," gives the very same extract, and says that "We cannot admit that the work of Hecatrus is on the subject of Ancient Britain," and estimates its value in the following extract from the works of an eminent Polish scholar (Lélewel, Pythéas, 45): "Hécatée a publié un fameux ouvrage dont le titre décèle "ne vieille idce poétique rajeunie sous sa plume. Elle devait s'allier aux nouvelles découvertes et $y$ prendre tne place éminente au détriment de la science et du bon sens. Ilécatée, énumerant tous les êtres mystérieux de la géographie septentrionale, enrichit leur nomenclature d'une rivière Scythique récenment trouvée en Orient par le conquérant, qu'il a appelée Parapamisos ; et plis encore des promontoires et des îles Celtiques, qu'il a probablement puisées dans les rélations véridiques de Pythéas pour les entrelacer dans les plages superboréennes."

The quotation from Diodorus is from his second book, but the whole of this se:ond book is dedicated solely to a description of Asia; and it is not until the fifth book is reached that he describes the British Isles, and with a very considerable degree of accuracy. (See Fergusson's "Rude Stone Monuments," p. 8).

I do not think, either, that "Nine Maidens" is simply an abbreviation of "Nineteen Mailens," frr, like "Nine Ladies" of Stant in Moor, in Derbyshire, it is a memorial circle.

Stone Henge, morewer, is much more probably a memorial circle, as its original name implies - "Stan Hengis" ; and commemorates the massacre of Vortigern's chiefs by Hengist in 462 A.D. The Rolliright circle probably commemorates the victory of Rollo over Eadward, circ. 913, whilst Avebury and Hakpen (520), Kit's Coty House (455), Long Meg and her Daughters (508-520), Stanton Drew (508-520), Arthur's 'Table, Arbor Lowe, Cumrew, Salkeld and Mayborough commemorale some of the victories of Arthur. 'That this is reasonable may be mentioned the facts that coins of Claudius Gothicus 1270 A.D.), Constantine the Great, Constantine junior, and Valentinian have been found at one or other.

Milverton, Leamington

SAND. S. STANLly

\section{The Forecasting of Barometric Variations}

IN a paper published in the Fournal of the Royal Meteorological Society, vol. x., p. 219 , 1884, I pointed out that during a series of years the barometric variations in Western India had presented certain features which, had they been known at the beginning of 1876 , and, indeed, at the beginning of 1872 , would have made it possible to have calculated with a consider able degree of precision and reliability the general course of the brometric variations from 1872 up to 1883 , in some cases three 